\title{
Persistent Contamination of Octopuses and Mussels with Lipophilic Shellfish Toxins during Spring Dinophysis Blooms in a Subtropical Estuary
}

\section{Luiz L. Mafra Jr. ${ }^{1, *}$, Daiana Lopes ${ }^{1}$, Vanessa C. Bonilauri ${ }^{1}$, Hajime Uchida ${ }^{2}$ and Toshiyuki Suzuki ${ }^{2}$}

1 Center for Marine Studies, Federal University of Paraná, P.O. Box 61, Pontal do Paraná, Paraná 83255-976, Brazil; E-Mails: daiana.aquicultura2011@gmail.com (D.L.); vancoq@ufpr.br (V.C.B.)

2 National Research Institute of Fisheries Science, 2-12-4 Fukuura, Kanazawa, Yokohama, Kanagawa 236-8648, Japan; E-Mails: huchida@affrc.go.jp (H.U.); tsuzuki@affrc.go.jp (T.S.)

* Author to whom correspondence should be addressed; E-Mail: luiz.mafra@ufpr.br; Tel.: +55-41-3511-8669; Fax: +55-41-3511-8648.

Academic Editors: Angela Capper and Cherie Motti

Received: 16 April 2015 / Accepted: 28 May 2015 / Published: 18 June 2015

\begin{abstract}
This study investigates the occurrence of diarrhetic shellfish toxins (DSTs) and their producing phytoplankton species in southern Brazil, as well as the potential for toxin accumulation in co-occurring mussels (Perna perna) and octopuses (Octopus vulgaris). During the spring in 2012 and 2013, cells of Dinophysis acuminata complex were always present, sometimes at relatively high abundances (max. 1143 cells $\mathrm{L}^{-1}$ ), likely the main source of okadaic acid (OA) in the plankton (max. $34 \mathrm{ng} \mathrm{L}^{-1}$ ). Dinophysis caudata occurred at lower cell densities in 2013 when the lipophilic toxins pectenotoxin-2 (PTX-2) and PTX-2 seco acid were detected in plankton and mussel samples. Here, we report for the first time the accumulation of DSTs in octopuses, probably linked to the consumption of contaminated bivalves. Perna perna mussels were consistently contaminated with different DSTs (max. $42 \mu \mathrm{g} \mathrm{kg}^{-1}$ ), and all octopuses analyzed $(n=5)$ accumulated OA in different organs/tissues: digestive glands $(\mathrm{DGs})>$ arms $>$ gills $>$ kidneys $>$ stomach + intestine. Additionally, similar concentrations of 7-O-palmytoyl OA and 7-O-palmytoly dinophysistoxin-1 (DTX-1) were frequently detected in the hepatopancreas of P. perna and DGs of $O$. vulgaris. Therefore, octopuses can be considered a potential vector of DSTs to both humans and top predators such as marine mammals.
\end{abstract}


Keywords: diarrheic shellfish poisoning; toxin accumulation; tissue distribution; Octopus vulgaris; Perna perna; Dinophysis acuminata complex

\section{Introduction}

Accumulation of Diarrhetic Shellfish Toxins (DSTs) in bivalve mollusks has caused expressive economic losses and human intoxication outbreaks in different parts of the globe (reviewed in Reguera et al. [1]). DSTs are acidic polyethers that may inhibit serine/threonine phosphoprotein phosphatases [2], causing diarrhea and other gastrointestinal symptoms in humans [3] during outbreaks of a food intoxication known as Diarrhetic Shellfish Poisoning (DSP). Since the late 1970s [4,5], DSP episodes have been reported worldwide following the consumption of contaminated bivalve mollusks, as assessed mainly by mice bioassay (MBA) and, more recently, by liquid chromatography-mass spectrometry (LC-MS) techniques [1]. The causative toxins, okadaic acid (OA) and its relative compounds, the dinophysistoxins (DTXs), can provoke not only phosphatase inhibition thus leading to DSP symptoms, but also immunotoxicity, genotoxicity and cytotoxicity to many cell types, (reviewed in Valdiglesias et al. [6]), and even tumor formation upon chronic exposure [7].

Okadaic acid and their analogs, DTX-1 and DTX-2, are produced by 10 species of the dinoflagellate Dinophysis, along with a few other species of the genera Phalacroma and Prorocentrum, which may retain varying concentrations of DSTs in their cells [1]. Among the toxin producers, the taxonomic complex composed by Dinophysis acuminata, Dinophysis ovum, and Dinophysis sacculus, the so-called D. acuminata complex, is the most widespread Dinophysis group in coastal areas [8] and is responsible for most DSP episodes. In addition, some Dinophysis species may produce another group of lipophilic shellfish toxins (LSTs), the pectenotoxins (PTXs), which are commonly found in plankton and bivalve tissues during DSP events and may interfere with MBA results, although the toxicity of these polyether-lactones to humans is uncertain because they are hepatotoxic to mice by intra-peritoneal injection but not by oral administration [9].

The amount of toxins accumulated by marine organisms will depend on the abundance of toxic phytoplankton cells they are exposed to. Even though Dinophysis spp. are usually minor components of mixed phytoplankton assemblages, cell densities as low as 100-200 cells $\mathrm{L}^{-1}$ may be enough to cause DSP outbreaks [3] if the cell toxin quota is sufficiently high. Moreover, feeding characteristics of the contaminated organisms, such as particle capture efficiency, capacity for selective feeding, ingestion rates, digestion efficiency, affinity for the toxic compounds, toxin transformation (i.e., metabolism and conjugation), and excretion [10], as well as their position in the water column [11], will ultimately determine the degree of toxin accumulation and its trophic transfer following contact with toxic Dinophysis cells in the water. Bivalves are the main vector for human intoxication, but other organisms, including polychaetes, ascidians [11], crabs [12] and fishes [13,14], have demonstrated the capacity to accumulate low DST levels following the ingestion of either toxic cells or contaminated bivalves.

There is currently no report of DST accumulation in octopuses, although they actively prey upon bivalves and may accumulate other shellfish toxins, such as the amnesic toxin domoic acid $[15,16]$ and paralytic toxins [17-20]. 
The present study investigates the presence of DSTs and other LSTs in the plankton and mussels (Perna perna) at two depths of a marina area in the outer Paranaguá Bay, southern Brazil, as well as in mussel-feeding octopuses (Octopus vulgaris) that reside that same area. Over two consecutive years (2012-2013), samples were obtained during the spring months, a period of typically higher cell densities of D. acuminata complex in the region. The occurrence of DSTs and other LSTs was evaluated in multiple tissues/organs of both mussels and octopuses to assess the risk for chronic LST exposure among human consumers and marine predators.

\section{Results and Discussion}

\subsection{Cell Abundance and Toxin Concentration in the Plankton}

D. acuminata was present in most (89\%) plankton samples, usually at cell densities $<100$ cells $\mathrm{L}^{-1}$. In October 2013, however, a maximum of 1143 cells $\mathrm{L}^{-1}$ was registered in the sampling area. During the same period, the occurrence of a Dinophysis species resembling D. parvula (64 cells $\left.\mathrm{L}^{-1}\right)$ and the maximum cell density of $D$. caudata $\left(192\right.$ cells L $\left.^{-1}\right)$ were also detected (Figure 1$)$. In fact, D. caudata was only found in the area in 2013. Dinophysis spp. usually represented a small portion $(<2.5 \%)$ of the total microphytoplankton cell abundance, except in October 2013, when approximately $10 \%$ of the total abundance (9.7\% at the surface and $10.7 \%$ near the bottom) consisted of Dinophysis cells (Figure 1). Cell densities as low as 100-200 cells L ${ }^{-1}$ may be sufficient to cause DSP outbreaks [3], especially if Dinophysis relative abundance and cell toxin quota are high.

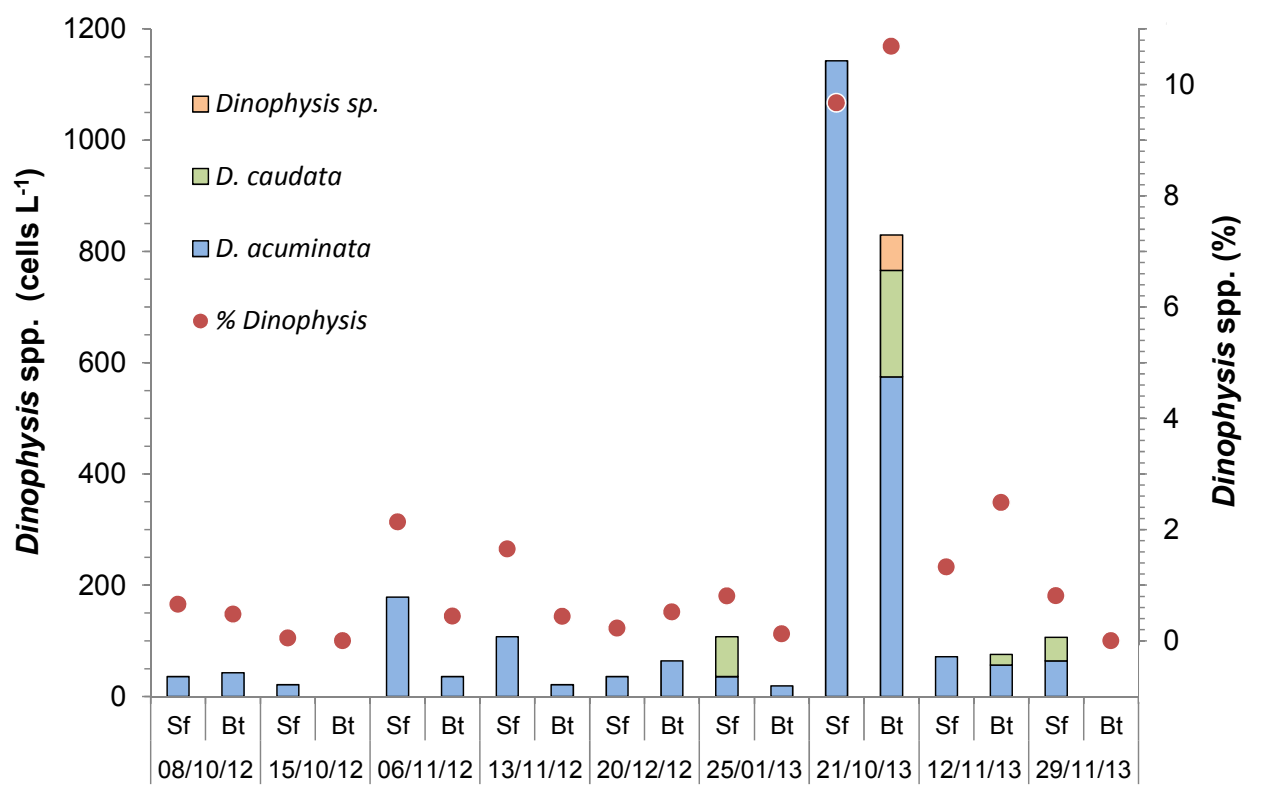

Figure 1. Cell density (cells $\mathrm{L}^{-1}$ ) and the relative abundance (\% of total microphytoplankton) of Dinophysis spp. in each sample collected from a marina area at the outer portion of Paranaguá Bay, southern Brazil. Sf: surface; Bt: bottom.

Different LSTs were detected in plankton, mussels and octopus samples (Figure 2). The highest OA concentrations in the plankton were measured at the surface, reaching $13.2 \mathrm{ng} \mathrm{L}^{-1}$ on 7 November 2012, $18.1 \mathrm{ng} \mathrm{L}^{-1}$ on 29 November 2013 and the maximum value of $34.1 \mathrm{ng} \mathrm{L}^{-1}$ on 21 October 2013 
(Figure 3a), coincident with the peaks in D. acuminata cell abundance. Average OA cell quotas ranged from 2.3 to $19.2 \mathrm{pg}$ OA Dinophysis cell $^{-1}$, which is within the normal range reported for the region (2.4-26.4 pg OA cell $\left.{ }^{-1}[14]\right)$.

D. acuminata complex was either the only (spring 2012) or the dominant (spring 2013) Dinophysis present in the samples, likely to be responsible for the OA found in the water column due to its overwhelming presence. In fact, species belonging to the D. acuminata complex are the main culprit for DSP episodes across the globe (reviewed in Reguera et al. [1]), although their toxin profile and cell quota may vary at a great extent according to the geographic location. In culture, LST cell quotas range from non-detected levels to $0.9 \mathrm{pg} \mathrm{OA} \mathrm{cell}{ }^{-1}, 1.8 \mathrm{pg}$ DTX-1 cell ${ }^{-1}$ and $20.4 \mathrm{pg}$ PTX-2 cell ${ }^{-1}$ in isolates from northwestern Atlantic [21-24]; and from non-detected levels to $12.2 \mathrm{pg} \mathrm{OA} \mathrm{cel1^{-1 }}$, from 0.2 to $4.8 \mathrm{pg}$ DTX-1 cell ${ }^{-1}$ and from 14.7 to $107 \mathrm{pg}$ PTX-2 cell ${ }^{-1}$ in isolates from Japan [25-27]. In some other areas, isolates belonging to the D. acuminata complex, including $D$. cf. ovum, may produce only OA, as reported in the Gulf of Mexico (12.6 pg cell $\left.{ }^{-1}[22,24]\right)$ and southern Brazil $\left(3.2-18 \mathrm{pg} \mathrm{cell}^{-1}[14]\right)$.
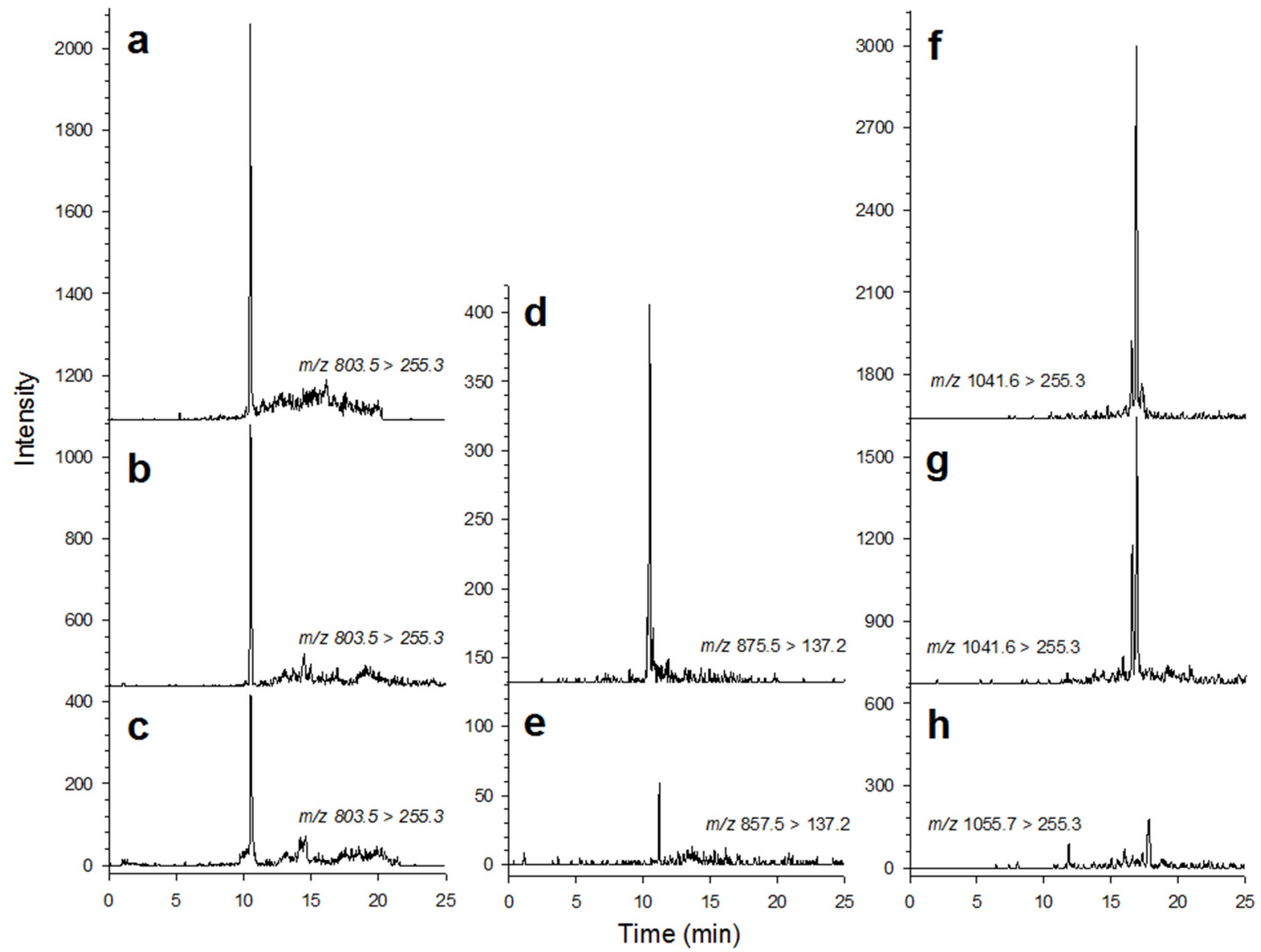

Figure 2. Multiple reaction monitoring (MRM) LC-MS/MS chromatograms of (a-c) okadaic acid (OA); (e) pectenotoxin-2 (PTX-2); (d) PTX-2 seco acid; (f,g) 7-O-palmytoyl $\mathrm{OA}$ and (h) 7-O-palmytoyl dinophysistoxin-1 (DTX-1) in selected samples of: (a,d,g) hepatopancreas of Perna perna mussels, (b,e) plankton, and (c) arms and (f,h) digestive glands of Octopus vulgaris from Paranaguá Bay, southern Brazil. 

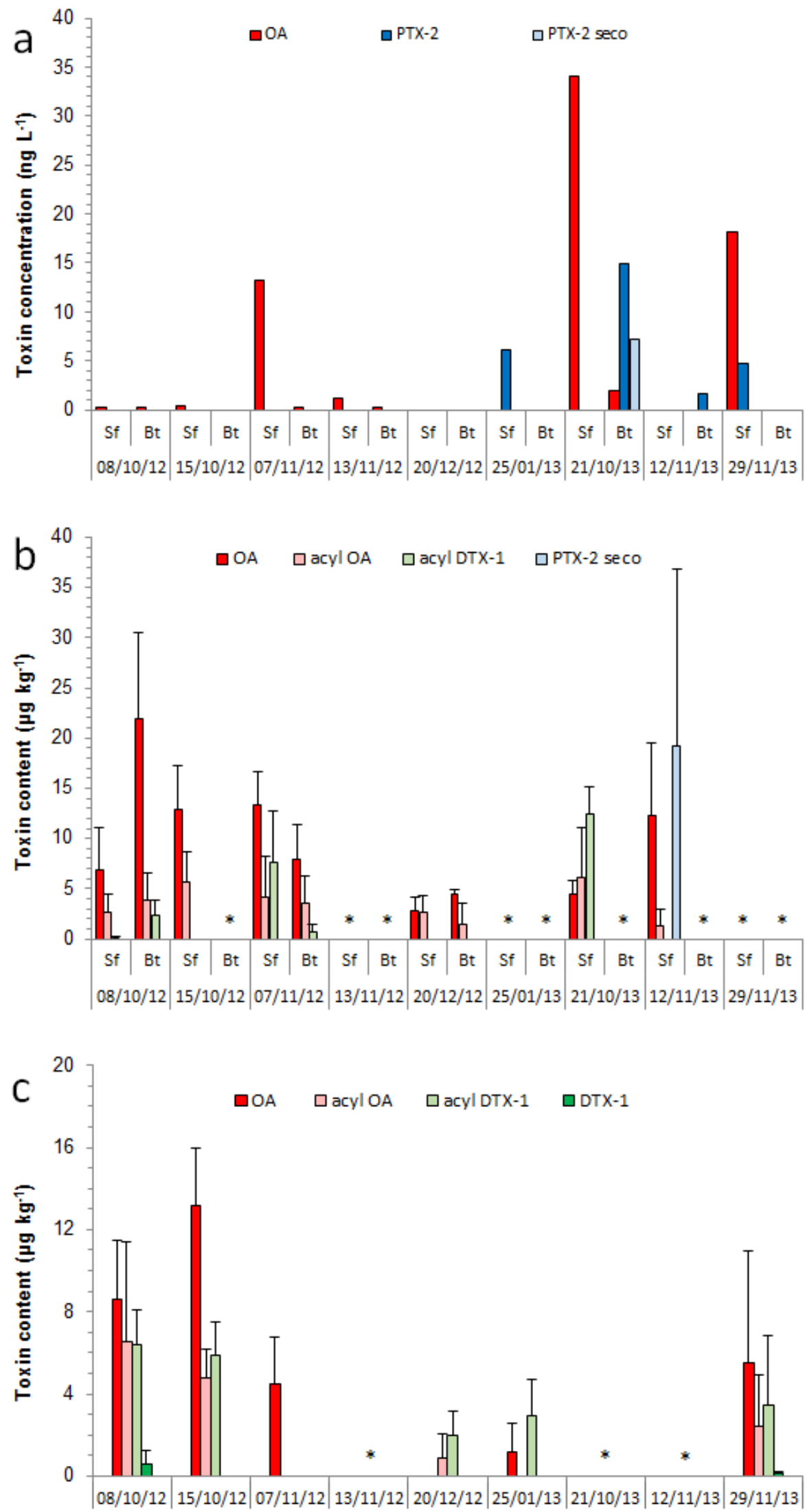

Figure 3. Toxin contents (mean + standard error) in (a) plankton; (b) whole mussels (reconstituted samples) and (c) octopus digestive glands sampled in Paranaguá Bay, southern Brazil. Asterisks indicate occasions when no samples were available. Sf: surface; Bt: bottom. 
During the 2013 bloom season, PTX-2 and PTX-2 seco acid were also detected in the plankton, coinciding with the presence of D. caudata in the water, and attained, respectively, up to 11.2 and $5.4 \mathrm{ng} \mathrm{L}^{-1}$ near the bottom on 21 November 2013 (Figure 3a).

\subsection{Toxin in Mussels and Octopuses}

Mussels were contaminated with OA (max. $21.9 \pm 8.6 \mu \mathrm{g} \mathrm{kg}^{-1}$ ) whenever samples were available during the study. In addition, 7-O-palmytoyl OA and 7-O-palmytoyl DTX-1 were occasionally found at lower concentrations (max. $6.1 \pm 4.9$ and $12.4 \pm 2.8 \mu \mathrm{g} \mathrm{kg}^{-1}$, respectively) (Figure 3b). Concentrations of DSTs in mussels were similar between sampling depths and among sampling campaigns, and there was no clear association with maximum OA levels measured in the plankton. Conversely, PTX-2 seco acid was detected in mussels in a single occasion, following the period when the maximum levels of PTX-2 were found in the plankton. OA was found more frequently (96\%) and at higher levels (up to $69.7 \mu \mathrm{g} \mathrm{kg}^{-1}$ ) in the hepatopancreas (HP) compared to the non-visceral (NV) tissues of mussels (42\%; max. $4.0 \mu \mathrm{g} \mathrm{kg}^{-1}$ ) (Table 1). On average, mussels accumulated 10 times higher OA levels in the HP than in the NV tissues. The metabolites 7-O-palmytoyl OA, 7-O-palmytoyl DTX-1 and PTX-2 seco acid were detected exclusively in the HP (Table 1), along with a different DTX-1 analogue (not shown), which exhibited the characteristic $\mathrm{m} / \mathrm{z} 255.1$ fragment, but slightly different MS/MS spectrum and retention time $(10.5 \mathrm{~min})$ than that usually obtained for DTX-1 (11.7 min). Additional MS/MS and NMR analysis will be conducted in order to elucidate the molecular structure of this novel DTX-1 analogue.

Table 1. Average (avg., \pm standard deviation) and maximum (max.) toxin levels measured in different tissues/organs of mussels Perna perna sampled in Paranaguá Bay, southern Brazil. Number of positive samples and the total number of samples analyzed $(n)$ are indicated in parenthesis. Each sample was composed of four pooled individuals. nd: non-detected.

\begin{tabular}{|c|c|c|c|c|c|c|c|c|c|}
\hline \multirow{2}{*}{ Tissue } & & \multicolumn{2}{|c|}{$\mathbf{O A}$} & \multicolumn{2}{|c|}{ acyl OA } & \multicolumn{2}{|c|}{ acyl DTX-1 } & \multicolumn{2}{|c|}{ PTX-2 seco } \\
\hline & & $\mu \mathrm{g} \mathrm{kg}^{-1}$ & $n$ & $\mu \mathrm{g} \mathrm{kg}^{-1}$ & $n$ & $\mu \mathrm{g} \mathrm{kg}^{-1}$ & $n$ & $\mu \mathrm{g} \mathrm{kg}^{-1}$ & $n$ \\
\hline \multirow{2}{*}{ Hepatopancreas } & avg. & $22.2 \pm 17.9$ & $(25 / 26)$ & $8.87 \pm 10.3$ & $(17 / 26)$ & $7.81 \pm 15.2$ & $(10 / 26)$ & $6.34 \pm 27.2$ & $(2 / 26)$ \\
\hline & $\max$. & 69.7 & & 43.2 & & 53.3 & & 137.0 & \\
\hline \multirow{2}{*}{$\begin{array}{c}\text { Non-visceral } \\
\text { tissues }\end{array}$} & avg. & $0.94 \pm 1.30$ & $(11 / 26)$ & nd & & nd & & nd & \\
\hline & $\max$. & 4.04 & & & & & & & \\
\hline
\end{tabular}

Although mussels did not accumulate DTX-1 at detectable levels, 37\% of the $P$. perna samples exhibited low levels of its acylated derivative, 7- $O$-palmytoyl DTX-1 (up to $16.9 \mu \mathrm{g} \mathrm{kg}^{-1}$ ), and $65 \%$ also presented low levels of 7-O-palmytoyl OA (up to $13.7 \mu \mathrm{g} \mathrm{kg}^{-1}$ ). The maximum total DST levels were approximately four-fold lower than the EU regulatory limit (RL) of $160 \mathrm{ng}$ OA equiv. $\mathrm{g}^{-1}$ [28], and similar to those found in oysters Crassostrea spp. sampled in January 2011 from the same region (up to $17.8 \mu \mathrm{g} \mathrm{kg}^{-1}$ [14]). In contrast, in neighboring areas of Santa Catarina State, $P$. perna mussels and, eventually, the oyster Crassostrea gigas have accumulated OA levels above the RL when exposed to similar to higher Dinophysis cell densities (i.e., $>1000$ cells $\mathrm{L}^{-1}$ ), leading to DSP outbreaks on some occasions [29,30]. 
In addition to DSTs, mussels sampled in the present study also accumulated PTX-2 seco acid, a common degradation product of PTX-2 in bivalves [9,31]. Since southern Brazilian populations of D. acuminata complex apparently produce only OA [14], D. caudata is probably the sole source of PTX-2 detected in the present study. The highest observed D. caudata cell abundances $\left(\sim 190\right.$ cells L $\left.{ }^{-1}\right)$ coincided with the maximum PTX-2 concentrations (up to $11.2 \mathrm{ng} \mathrm{\textrm {L } ^ { - 1 }}$ ) reported in the plankton fraction in late November 2013. Assuming no other producer, average PTX-2 contents ranged from 58.2 to $112 \mathrm{pg}$ D. caudata cell $^{-1}$. Moreover, the presence of PTX-2 seco acid in one of our plankton samples must be related to the ingestion (and further digestion) of $D$. caudata cells by zooplankton. Although D. caudata has been previously cultivated in the laboratory [14,32], the only reported toxin profile (7.9-56.5 pg OA; 0.0-53.9 pg DTX-1 cell ${ }^{-1}$ ) was obtained from picked wild cells in the Philippines, when no PTX analysis was performed [33]. Recently, PTX-2 was the only LST detected in the dissolved fraction of a D. caudata culture isolated from Japanese waters [34], supporting the indication of this species as an important source of PTX-2 in southern Brazil, what remains to be unambiguously confirmed and quantified in the field.

In November 2013, toxin concentrations reached $34.1 \mathrm{ng} \mathrm{OA} \mathrm{L} \mathrm{H}^{-1}$ and $11.2 \mathrm{ng} \mathrm{PTX}-2 \mathrm{~L}^{-1}$ in our plankton samples, when the cell densities of both $D$. acuminata complex and D. caudata were the highest (1140 and 190 cells $\mathrm{L}^{-1}$, respectively). In a similar study in Jinhae Bay, Korea, equivalent concentrations of PTX-2 (8.1 ng L $\left.{ }^{-1}\right)$ but much lower levels of OA and DTX-1 (0.8 $\mathrm{ng} \mathrm{L}^{-1}$ each) were detected in the plankton when D. acuminata reached 1000 cells $\mathrm{L}^{-1}$ [35]. Notwithstanding, mussels Mytilus galloprovincialis from Jinhae Bay accumulated relatively higher LST levels in their HPs (up to $168 \mathrm{ng} \mathrm{OA} \mathrm{g}{ }^{-1}, 171 \mathrm{ng}$ DTX-1 g $\mathrm{g}^{-1}$ and $105 \mathrm{ng}$ PTX-2 $\mathrm{g}^{-1}$ ) compared to those found in $P$. perna in the present study (Table 1), suggesting an inferior capacity for toxin accumulation in the latter. In M. galloprovincialis, LST levels varied accordingly to both Dinophysis cell abundance and toxin concentrations in the plankton [35]. However, this was not always the case with $P$. perna mussels in the present study (see 2012 data in Figures 1 and 3), what may be related to their much faster OA detoxification rates $\left(0.023 \mathrm{~h}^{-1}\right)$, as calculated during simulated Dinophysis blooms in the laboratory [30]. In addition, 7-O-palmytoylated derivatives of OA and DTX-1 attained slightly greater concentrations than those of OA in the HPs of $P$. perna, suggesting fast toxin transformation and elimination in that organ. When present in the other soft tissues, OA concentrations were, on average, 10-fold (3.9-26-fold) lower than those measured in the HPs.

Besides being harvested for human consumption, mussels contaminated with low to moderate toxin concentrations can be consumed by a wide range of marine benthic predators, such as fish [13], crustaceans [36], gastropods [37] and cephalopods [18]. At that point, these organisms may become intoxicated and/or act as a vector of toxins to higher trophic levels. In the present study, LST-contaminated mussels living on the columns of a wharf may have served as an important food item for a local population of common octopuses, Octopus vulgaris, as evidenced by the presence of abundant empty shells around their sheltering holes.

All five octopuses sampled during this study accumulated toxins in at least two different organs/tissues each. The highest OA concentrations were detected in the digestive glands (DGs; max. $17.3 \mu \mathrm{g} \mathrm{kg}^{-1}$ ) of a male individual (1130 g; $14.1 \mathrm{~cm}$ mantle length, ML) sampled on 15 November 2012 (Figure 3c), and in the gills (max. $13.2 \mu \mathrm{g} \mathrm{kg}^{-1}$ ) and arms (max. $43.7 \mu \mathrm{g} \mathrm{kg}^{-1}$ ) of a smaller male (870 g; $13.5 \mathrm{~cm} \mathrm{ML)}$ sampled on 20 December 2012. Lower toxin levels were reported in the DGs (max. $7.9 \mu \mathrm{g} \mathrm{kg}^{-1}$ ), 
gills (max. $8.0 \mu \mathrm{g} \mathrm{kg}^{-1}$ ) and kidneys (max. $7.2 \mu \mathrm{g} \mathrm{kg}^{-1}$ ) of two female individuals sampled on 7 November 2012 and 25 January 2013 (1450 and $890 \mathrm{~g} ; 16.4$ and $14.9 \mathrm{~cm}$ ML, respectively). In addition to OA, 7-O-palmytoyl OA (max. $14.4 \mu \mathrm{g} \mathrm{kg}-1$ ) and 7-O-palmytoyl DTX-1 (max. $8.8 \mu \mathrm{g} \mathrm{kg}^{-1}$ ) were also found in the DGs of different octopuses, and DTX-1 and 7-O-palmytoyl DTX-1 were detected, respectively, in the DG and the stomach + intestine fraction of a large male (2220 g; $14.9 \mathrm{~cm} \mathrm{ML})$ sampled on 8 November 2012 (Figure 3c, Table 2). Finally, 7-O-palmytoyl OA was also found at low levels in the stomach + intestine, gills and kidneys of the octopus sampled on 15 November 2012 (Table 2), while PTX-2 and PTX-2 seco acid were not detected in any of the five octopuses. DTX-2 and PTX-6 were not found in any sample analyzed during this study, including plankton, mussels and octopuses.

Table 2. Average (avg., \pm standard deviation) and maximum (max.) toxin levels measured in different tissues/organs of octopuses Octopus vulgaris sampled in Paranaguá Bay, southern Brazil. Number of contaminated individuals and the total number of individuals analyzed $(n)$ are indicated in parenthesis. nd: non-detected.

\begin{tabular}{|c|c|c|c|c|c|c|c|c|c|}
\hline \multirow[b]{2}{*}{ Tissue } & & \multicolumn{2}{|l|}{$\mathbf{O A}$} & \multicolumn{2}{|c|}{ acyl OA } & \multicolumn{2}{|c|}{ acyl DTX-1 } & \multicolumn{2}{|l|}{ DTX-1 } \\
\hline & & $\operatorname{ng~g}^{-1}$ & $n$ & $\mathrm{ng} \mathrm{g}^{-1}$ & $n$ & $\mathbf{n g ~ g}^{-1}$ & $n$ & $\mathbf{n g ~ g}^{-1}$ & $n$ \\
\hline \multirow{2}{*}{ Digestive gland } & avg. & $5.49 \pm 5.66$ & $(4 / 5)$ & $2.44 \pm 3.94$ & $(3 / 5)$ & $3.41 \pm 3.02$ & $(4 / 5)$ & $0.11 \pm 0.44$ & $(1 / 5)$ \\
\hline & $\max$. & 17.3 & & 14.4 & & 8.8 & & 1.7 & \\
\hline \multirow{2}{*}{ Stomach + intestine } & avg. & $0.43 \pm 1.70$ & $(1 / 5)$ & $0.06 \pm 0.23$ & $(1 / 5)$ & $0.04 \pm 0.16$ & $(1 / 5)$ & nd & \\
\hline & $\max$. & 6.6 & & 0.9 & & 0.6 & & & \\
\hline \multirow{2}{*}{ Gills } & avg. & $2.48 \pm 3.94$ & $(3 / 5)$ & $0.02 \pm 0.09$ & $(1 / 5)$ & nd & & nd & \\
\hline & $\max$. & 13.2 & & 0.4 & & & & & \\
\hline \multirow{2}{*}{ Kidneys } & avg. & $1.12 \pm 2.48$ & $(2 / 5)$ & $0.10 \pm 0.33$ & $(1 / 5)$ & nd & & nd & \\
\hline & $\max$. & 7.3 & & 1.0 & & & & & \\
\hline \multirow{2}{*}{ Arm } & avg. & $3.72 \pm 11.3$ & $(2 / 5)$ & nd & & nd & & nd & \\
\hline & $\max$. & 43.7 & & & & & & & \\
\hline Gonads & $\begin{array}{l}\text { avg. } \\
\text { max. }\end{array}$ & nd & & nd & & nd & & nd & \\
\hline Mantle & $\begin{array}{l}\text { avg. } \\
\text { max. }\end{array}$ & nd & & nd & & nd & & nd & \\
\hline
\end{tabular}

Thus, based on the present findings in Southern Brazil, octopuses can be considered an additional vector of these toxins to both humans and top predators such as marine mammals, known to prey upon octopuses and other cephalopods [38,39]. In fact, this may be also relevant in other regions worldwide, since both LST-producing dinoflagellates [40] and O. vulgaris [41] are globally distributed in tropical to temperate waters, and these octopuses are able to retain large amounts of biocumulative substances like heavy metals (e.g., [42,43]) and other algal toxins, such as paralytic shellfish toxins (PSTs), domoic acid (DA) and palytoxins (PITXs) (reviewed in Lopes et al. [44]).

Octopuses, including an unidentified species from Australia and the common octopus O. vulgaris, have shown the capacity to accumulate large amounts of PSTs [17-20]. Likewise, O. vulgaris and two other octopus species from the Portuguese continental coast, Eledone cirrhosa and E. moschata, were found to contain relatively high concentrations of the amnesic shellfish toxin, domoic acid (DA) $[15,16]$. By far, the highest PST and DA levels are observed in the octopus DGs. O. vulgaris, for instance, 
accumulated up to $2680 \mathrm{ng}$ STX equiv. $\mathrm{g}^{-1}$ in the DG following the consumption of contaminated mussels during toxic blooms in Portugal, while other organs involved in digestion (stomach and salivary glands) and excretion (kidneys and branchial hearts) exhibited approximately eight to 16 times lower toxin concentrations [19]. This was further confirmed under laboratory conditions, with O. vulgaris accumulating up to three orders of magnitude higher PST levels in the DG compared to the kidneys [20]. Finally, DA concentrations in the DG of Portuguese O. vulgaris were approximately three times higher than those measured in the branchial hearts, and one to two orders of magnitude higher than those eventually found in the kidneys, digestive tract (stomach, spiral caecum and intestine), gills, systemic heart, posterior salivary glands and mantle [15]. In the present study, the tissue distribution of LSTs varied among the five individuals investigated, however, total toxin levels $\left(\mathrm{OA}+\mathrm{DTX}-1+\right.$ acyl OA + acyl DTX-1) were, on average, much higher in the DG $\left(11.5 \mu \mathrm{g} \mathrm{kg}^{-1}\right)$ than in the arms $\left(3.7 \mu \mathrm{g} \mathrm{kg}^{-1}\right)$, gills $\left(2.5 \mu \mathrm{g} \mathrm{kg}^{-1}\right)$, kidneys $\left(1.2 \mu \mathrm{g} \mathrm{kg}^{-1}\right)$ and stomach + intestine $\left(0.5 \mu \mathrm{g} \mathrm{kg}^{-1}\right)$. Toxin levels in mantle and gonads were always below the detection limit (i.e., $0.11 \mu \mathrm{g} \mathrm{kg}^{-1}$ ).

The higher LST levels detected in the DGs of O. vulgaris support their role as the primary site for intracellular digestion, absorption and storage in cephalopods [45]. In four out of five octopuses collected in the present study, DG samples contaminated with OA also contained the acylated metabolites 7-O-palmytoyl OA and/or 7-O-palmytoyl DTX-1, indicating active LST transformation at that organ. Acylated derivatives were much less frequent in other octopus tissues where OA was detected at lower levels, such as the gills, suggesting that a limited fraction of the toxin may enter the blood system and be distributed prior to its absorption by the digestive system. In addition, toxin detection in the kidneys may indicate that these organs are involved in excretion of LSTs by octopuses, as first suggested for PSTs [19] and DA [15].

Surprisingly, OA was also detected in the arms of two octopuses in our study, reaching relatively high yet extremely variable toxin levels $(\mathrm{CV}=124 \%-173 \%)$. For instance, OA levels varied from $<1.0$ to $43.7 \mu \mathrm{g} \mathrm{kg}^{-1}$ within a single arm. Since our replicate samples were composed of different pieces of tissue from a single octopus arm, this suggests strong spatial toxin aggregation into putative high affinity sites, as reported for saxitoxin (STX) in the siphons of butter clams, Saxidomus giganteus ([46] and references therein). In the case of octopus, this may be related to the practice of discarding the very tip of the arms in some traditional Western Japanese cuisine supposedly avoiding consumer intoxication by bacteria and marine toxins, although we cannot trace back which part of the octopus arms contained the higher toxin levels in our study. In fact, STX has been found at relatively high levels in the arms of an unidentified octopus from Australia [18], but never in O. vulgaris, despite the extremely high toxin contents measured in their DGs [19]. The possibility that octopuses may also accumulate low toxin levels in other organ/tissues not related to digestion and excretion, such as the mantle and gonads, cannot be disregarded and should be further assessed in laboratory-based toxin dynamics studies, and/or during more toxic episodes of Dinophysis natural blooms. 


\section{Experimental Section}

\subsection{Field Sampling}

Nine sampling campaigns were performed from 8 October 2012 to 25 January 2013 and from 21 October to 29 November 2013 at a marina area in the outer sector of Paranaguá Bay, southern Brazil $\left(25^{\circ} 32^{\prime} 82.2^{\prime \prime} \mathrm{S} ; 48^{\circ} 23^{\prime} 28.3^{\prime \prime} \mathrm{W}\right)$. P. perna mussels colonize the columns of a wharf located in this area and are used as part of the diet of a resident $O$. vulgaris population [47].

Phytoplankton samples were always taken at flood to high tide using Van Dorn bottles at sub-surface $(0.5 \mathrm{~m})$ and near the bottom (9-9.5 m depth) for cell density determination and toxin analysis. Samples were fixed with 1\% neutral Lugol's solution, and Dinophysis spp. cells were counted on entire Utermöhl chambers under the microscope, after sedimentation of $50 \mathrm{~mL}$. Other microphytoplankton cells $(>20 \mu \mathrm{m})$ were counted in transects until at a minimum of 300 cells had been computed. Dinophysis spp. cell density was expressed as cells $\mathrm{L}^{-1}$ and the relative abundance as percent of total microphytoplankton cells, for both surface and bottom samples. Concurrent to bottle sampling, oblique net trawling (20 $\mu \mathrm{m}$ mesh size) was performed for taxonomic identification. Dinophysis cells were observed under the light microscope (Zeiss ${ }^{\circledR}$ Axiovert A1), and randomly selected individuals were measured using a coupled camera (Zeiss ${ }^{\circledR}$ AxioCam ERc5s) and the image processing software AxioVision 4. Cell features, shape and measurements were compared to the literature [48-50] for taxonomic identification at species level.

Aliquots $(100 \mathrm{~mL})$ of the bottle samples were gently passed through glass microfiber filters (Whatman ${ }^{\circledR} \mathrm{GF} / \mathrm{F}$ ) and the retained material was kept frozen for further toxin analysis. In addition, 100-mL aliquots of the net concentrated samples were also filtered for toxin determination in the case toxin levels in plankton were below the detection limit. In this case, triplicate $2-25 \mathrm{~mL}$ aliquots of the net-concentrated samples were settled, and Dinophysis spp. cells were counted on entire chambers, as previously described, in order to calculate the average cellular toxin content (expressed in pg cell ${ }^{-1}$ ).

Mussels and octopuses were simultaneously sampled by scuba diving during the plankton sampling campaigns. Mussels were manually removed from the wharf columns at sub-surface and near the bottom, and immediately transported to the laboratory. After external cleaning, mussel shells were opened and the market-sized individuals were carefully dissected into hepatopancreas (HP) and non-visceral (NV) soft tissues. Samples ( $n=3$ per depth) were composed of pooled tissue fractions from four mussels, yielding at least $5 \mathrm{~g}$ of HP or $10 \mathrm{~g}$ of $\mathrm{NV}$ tissues each, and individually frozen until further processing. Octopuses, when available, were collected from their holes near the wharf and frozen upon arrival at the laboratory. Prior to the toxin analysis, adult individuals were dissected during thawing to prevent leaking of fluids and contamination of surrounding organs. Aliquots $(n=3$; 1-5 g each) of the following tissues/organs were obtained and kept frozen into individual tubes for further analysis: digestive glands, stomach + intestine, gills, kidneys, gonads, arms and mantle. Only two replicate samples were obtained from the kidneys due to their reduced size. 


\subsection{Toxin Analysis}

Toxins were extracted from the plankton samples after adding $5 \mathrm{~mL}$ of $100 \%$ methanol (JT Baker, Phillipsburg, NJ, USA) to each filter. Plankton cells retained in the filters were disrupted using a sonic dismembrator (Cole Parmer CPX130, Vernon Hills, IL, USA), applying pulses of $2 \mathrm{~s}$ with 1-s intervals for $2 \mathrm{~min}$, at $70 \%$ amplitude. Extracts were then centrifuged for $10 \mathrm{~min}$ at $2400 \mathrm{rpm}$; a $0.5-\mathrm{mL}$ aliquot of the supernatant was completely evaporated with nitrogen and stored in freezer for further toxin analysis, when the same volume of methanol was used to reconstitute the samples. Bivalve and octopus tissues were processed following a similar protocol, except that methanol was added on a $9 \mathrm{~mL}: 1 \mathrm{~g}$ proportion, with the sonicator set at $80 \%$ amplitude, applying pulses of $3 \mathrm{~s}$ and intervals of $1 \mathrm{~s}$ for 3 min. Samples of octopus mantle and arms were first ground with an Ika Ultra-Turrax ${ }^{\circledR}$ disperser.

Toxin analysis was conducted by liquid chromatography-tandem mass spectrometry (LC-MS/MS) using an Agilent 1200 series (Agilent Technologies, Palo Alto, CA, USA) LC system coupled to a hybrid triple quadrupole/linear ion trap mass spectrometer Q-trap ${ }^{\circledR} 3200$ (AB-SCIEX, Framinghan, MA, USA) equipped with a TurboIonSpray interface. LC-MS/MS analysis was carried out according to the method described in Suzuki et al. [51], with a slight modification - the use of multiple reaction monitoring (MRM) instead of selected ion monitoring (SIM) [52]. Separations were performed on a Quicksilver cartridge column $(50 \mathrm{~mm} \times 2.1 \mathrm{~mm}$ i.d.) packed with $3 \mu \mathrm{m}$ Hypersil-BDS-C8 (Thermo Fisher Scientific, Waltham, MA, USA) maintained at $20{ }^{\circ} \mathrm{C}$. Both eluent A (water) and B (95\% acetonitrile) contained $2 \mathrm{mM}$ ammonium formate and $50 \mathrm{mM}$ formic acid [53,54]. Linear gradient elution from $20 \%$ to $100 \%$ B was performed over $10 \mathrm{~min}$ and then held at $100 \% \mathrm{~B}$ for $15 \mathrm{~min}$, followed by re-equilibration with $20 \% \mathrm{~B}$ for $13 \mathrm{~min}$. Flow rate was $0.2 \mathrm{~mL} \mathrm{~min}{ }^{-1}$ and the injection volume $5 \mu \mathrm{L}$. The LC effluent was introduced into the TurboIonSpray interface without splitting. High-purity air, heated to $500{ }^{\circ} \mathrm{C}$, was used as the nebulizing gas. The following SRM transitions were monitored: $m / z \quad 803.5 \rightarrow 255.1$ for OA and DTX-2; $m / z 817.5 \rightarrow 255.1$ for DTX-1; $m / z 1041.6 \rightarrow 255.3$ for 7-O-palmytoyl OA, $m / z \quad 1055.7 \rightarrow 255.3$ for 7-O-palmytoly DTX-1, $m / z \quad 857.5 \rightarrow 137.2$ for PTX-2, $m / z \quad 875.5 \rightarrow 137.2$ for PTX-2 seco acid, $m / z \quad 873.5 \rightarrow 137.2$ for PTX-1 and $m / z \quad 887.5 \rightarrow 519.4$ for PTX-6 [53], with OA, DTX-1 and PTX-2 concentrations calculated from a calibration curve made of serial dilutions of the reference standards available at FRA-NRIFS, Yokohama, Japan, using the software Analyst ${ }^{\circledR}$. The calculated detection limits were $0.011,0.018$ and $0.030 \mathrm{ng} \mathrm{mL}^{-1}$ for OA, DTX-1 and PTX-2, respectively.

\section{Conclusions}

This is the first report of DST accumulation in the common octopus (O. vulgaris), probably linked to the consumption of contaminated bivalves during periods when Dinophysis spp. were persistently present at moderate cell abundances in the water. All five octopuses analyzed in the present investigation accumulated DSTs in different organs/tissues, including their edible arms. Likewise, mussels sampled near the octopus shelters were consistently contaminated, containing low to moderate DST levels.

Over the sampling period (spring seasons of 2012 and 2013), D. acuminata complex were the dominant Dinophysis species in the plankton (up to 1140 cells $\mathrm{L}^{-1}$ ), being likely the main source of 
DSTs in the area. A second Dinophysis species, D. caudata, occurred in 2013 when PTX-2 and PTX-2 seco acid were detected in plankton and mussel samples.

Since both $O$. vulgaris and DST-producing dinoflagellates are distributed worldwide, toxin accumulation in octopuses is expected to occur in other regions of the globe. Therefore, octopuses can be considered a potential vector of DSTs to both humans and top predators such as marine mammals, representing a risk for diarrheic shellfish poisoning (DSP) outbreaks and perhaps other sub lethal negative effects upon recurrent exposure. The capacity for toxin transfer and its retention into edible tissues must be better investigated in octopuses in order to assess whether this important fishing product represents a risk for human health in areas subjected to recurrent toxic algal blooms.

\section{Acknowledgments}

The authors would like to thank Humberto N. Gerum and Fabricio S. Mazzini for their valuable assistance with the mussel and octopus sampling, as well as Tiago M. Lenz for his help during tissue dissection. We are also grateful for the Funding Agency of Paraná State (Fundação Araucária, 567/2014) for the research grant awarded to L.L.M. Jr.

\section{Author Contributions}

D.L. collected the samples and extracted the toxins from plankton, mussels and octopus samples; V.C.B. identified and counted the plankton samples; H.U., T.S. and L.L.M.Jr. performed the LC-MS/MS analysis, processed and interpreted the toxin data. L.L.M.Jr. also designed the study, performed the integrated analysis of the data and wrote the manuscript.

\section{Conflicts of Interest}

The authors declare no conflict of interest.

\section{References}

1. Reguera, B.; Riobó, P.; Rodríguez, F.; Díaz, P.A.; Pizarro, G.; Paz, B.; Franco, J.M.; Blanco, J. Dinophysis Toxins: Causative Organisms, Distribution and Fate in Shellfish. Mar. Drugs 2014, 12, 394-461.

2. Cohen, P.; Holmes, C.F.B.; Tsukitani, Y. Okadaic acid, a new probe for studying cellular regulation. Trends Biochem. Sci. 1990, 15, 98-102.

3. Yasumoto, T.; Murata, M.; Oshima, Y.; Sano, M.; Matsumoto, G.; Clardy, J. Diarrhetic shellfish toxins. Tetrahedron 1985, 41, 1019-1025.

4. Yasumoto, T.; Oshima, Y.; Yamaguchi, M. Occurrence of a new type of shellfish poisoning in the Tohoku district. J. Nippon Suisan Gakkaishi 1978, 44, 1249-1255.

5. Yasumoto, T.; Oshima, Y.; Sugawara, W.; Fukuyo, Y.; Oguri, H.; Igarashi, T.; Fujita, N. Identification of Dinophysis fortii as the causative organism of diarrhetic shellfish poisoning. Bull. Jpn. Soc. Sci. Fish. 1980, 46, 1405-1411.

6. Valdiglesias, V.; Prego-Faraldo, M.V.; Pásaro, E.; Méndez, J.; Laffon, B. Okadaic Acid: More than a Diarrheic Toxin. Mar. Drugs 2013, 11, 4328-4349. 
7. Fujiki, H.; Suganuma, M. Unique features of the okadaic acid activity class of tumor promoters. J. Cancer Res. Clin. Oncol. 1999, 125, 150-155.

8. Moestrup, Ø.; Akselman, R.; Fraga, S.; Hansen, G.; Hoppenrath, M.; Iwataki, M.; Komárek, J.; Larsen, J.; Lundholm, N.; Zingone, A. (Eds.) IOC-UNESCO Taxonomic Reference List of Harmful Micro Algae. Available online: http:/www.marinespecies.org/HAB (accessed on 20 March 2015).

9. Miles, C.O; Wilkins, A.L.; Munday, R.; Dines, M.H.; Hawkes, A.D.; Briggs, L.R.; Sandvik, M.; Jensen, D.J.; Cooney, J.M.; Holland, P.T.; et al. Isolation of pectenotoxin-2 from Dinophysis acuta and its conversion to pectenotoxin-2 seco acid, and preliminary assessment of their acute toxicities. Toxicon 2004, 43, 1-9.

10. Bricelj, V.M.; Shumway, S.E. Paralytic shellfish toxins in bivalve molluscs: Occurrence, transfer kinetics and biotransformation. Rev. Fish. Sci. 1998, 6, 315-383.

11. Reizopoulou, S.; Strogyloudi, E.; Giannakourou, A.; Pagou. K.; Hatzianestis, I.; Pyrgaki, C.; Granéli, E. Okadaic acid accumulation in macrofilter feeders subjected to natural blooms of Dinophysis acuminata. Harmful Algae 2008, 7, 228-234.

12. Vale, P.; Sampayo, M.A.M. First confirmation of human diarrhoeic poisonings by okadaic acid esters after ingestion of razor clams (Solen marginatus) and green crabs (Carcinus maenas) in Aveiro lagoon, Portugal and detection of okadaic acid esters in phytoplankton. Toxicon 2002, 40, 989-996.

13. Sipiä, V.; Kankaanpää, H.; Meriluoto, J. The first observation of okadaic acid in flounder in the Baltic Sea. Sarsia 2000, 85, 471-475.

14. Mafra, L.L., Jr.; Tavares, C.P.S.; Schramm, M.A. Diarrheic toxins in field-sampled and cultivated Dinophysis spp. cells from southern Brazil. J Appl .Phycol. 2014, 26, 1727-1739.

15. Costa, P.R.; Rosa, R.; Sampayo, M.A.M. Tissue distribution of the amnesic shellfish toxin, domoic acid, in Octopus vulgaris from the Portuguese coast. Mar. Biol. 2004, 144, 971-976.

16. Costa, P.R.; Rosa, R.; Pereira, J.; Sampayo, M.A.M. Detection of domoic acid, the amnesic shellfish toxin, in the digestive gland of Eledone cirrhosa and E. moschata (Cephalopoda, Octopoda) from the Portuguese coast. Aquat. Living Resour. 2005, 18, 395-400.

17. Robertson, A.; Stirling, D.; Robillot, C.; Llewellyn, L.; Negri, A. First report of saxitoxin in octopi. Toxicon 2004, 44, 765-771.

18. Costa, P.R.; Botelho, M.J.; Rodrigues, S.M. Accumulation of paralytic shellfish toxins in digestive gland of Octopus vulgaris during bloom events including the dinoflagellate Gymnodinium catenatum. Mar. Pollut. Bull. 2009, 58, 1739-1765.

19. Monteiro, A.; Costa, P.R. Distribution and selective elimination of paralytic shellfish toxins in different tissues of Octopus vulgaris. Harmful Algae 2011, 10, 732-737.

20. Lopes, V.M.; Baptista, M.; Repolho, T.; Rosa, R.; Costa, P.R. Uptake, transfer and elimination kinetics of paralytic shellfish toxins in common octopus (Octopus vulgaris). Aquat. Toxicol. 2014, 146, 205-211.

21. Hackett, J.D.; Tong, M.; Kulis, D.M.; Fux, E.; Hess, P.; Bire, R.; Anderson, D.M. DSP toxin production de novo in cultures of Dinophysis acuminata (Dinophyceae) from North America. Harmful Algae 2009, 8, 873-879. 
22. Fux, E.; Smith, J.L.; Tong, M.; Guzman, L.; Anderson, D.M. Toxin profiles of five geographical isolates of Dinophysis spp. from North and South America. Toxicon 2012, 57, 275-287.

23. Tong, M.; Kulis, D.M.; Fux, E.; Smith, J.L.; Hess, P.; Zhou, Q.X.; Anderson, D.M. The effects of growth phase and light intensity on toxin production by Dinophysis acuminata from the northeastern United States. Harmful Algae 2011, 10, 254-264.

24. Tong, M.; Smith, J.L.; Richlen, M.; Steidinger, K.A.; Kulis, D.M.; Fux, E.; Anderson, D.M. Characterization and comparison of toxin-producing isolates of Dinophysis acuminata from New England and Canada. J. Phycol. 2015, 51, 66-81.

25. Kamiyama, T.; Suzuki, T. Production of dinophysistoxin-1 and pectenotoxin-2 by a culture of Dinophysis acuminata (Dinophyceae). Harmful Algae 2009, 8, 312-317.

26. Kamiyama, T.; Nagai, S.; Suzuki, T.; Miyamura, K. Effect of temperature on production of okadaic acid, dinophysistoxin-1, and pectenotoxin-2 by Dinophysis acuminata in culture experiments. Aquat. Microb. Ecol. 2010, 60, 193-202.

27. Nagai, S.; Suzuki, T.; Nishikawa, T.; Kamiyama, T. Differences in the production and excretion kinetics of okadaic acid, dinophysistoxin-1, and pectenotoxin-2 between cultures of Dinophysis acuminata and Dinophysis fortii isolated from western Japan. J. Phycol. 2011, 47, 1326-1337.

28. Report of the Joint FAO/IOC/WHO ad hoc Expert Consultation on Biotoxins in Bivalve Molluscs. Available online: http://unesdoc.unesco.org/images/0013/001394/139421e.pdf (accessed on 8 April 2015).

29. Proença, L.A.O.; Schramm, M.A.; Tamanaha, M.S.; Alves, T.P. Diarrhoetic shellfish poisoning (DSP) outbreak in subtropical southwest Atlantic. Harmful Algae News 2007, 33, 19-20.

30. Mafra, L.L., Jr.; Ribas, T.; Alves, T.P.; Proença, L.A.O.; Schramm, M.A.; Uchida, H.; Suzuki, T. Differential okadaic acid accumulation and detoxification by oysters and mussels during natural and simulated Dinophysis blooms. Fish. Sci. 2015, doi:10.1007/s12562-015-0882-7.

31. Suzuki, T.; Mackenzie, L.; Stirling, D.; Adamson, J. Pectenotoxin-2 seco acid: A toxin converted from pectenotoxin-2 by the New Zealand Greenshell mussel, Perna canaliculus. Toxicon 2001, $39,507-514$.

32. Nishitani, G.; Nagai, S.; Sakiyama, S.; Kamiyama, T. Successful cultivation of the toxic dinoflagellate Dinophysis caudata (Dinophyceae). Plankton Benthos Res. 2008, 3, 78-85.

33. Marasigan, A.N.; Sato, S.; Fukuyo, Y.; Kodama, M. Accumulation of a high level of diarrhetic shellfish toxins in the green mussel Perna viridis during a bloom of Dinophysis caudata and Dinophysis miles in Saipan Bay, Panay Island, the Philippines. Fish. Sci. 2001, 67, 994-996.

34. Mafra, L.L., Jr. (Federal University of Paraná State, Curitiba, Brazil); Nagai, S.; Uchida, H.; Suzuki, T. (National Research Institute of Fisheries Science, Yokohama, Japan). Unpublished work, 2014.

35. Kim, J.H.; Lee, K.J.; Suzuki, T.; Kang, Y.S.; Kim, P.H.; Song, K.C.; Lee, T.S. Seasonal variability of lipophilic shellfish toxins in bivalves and waters, and abundance of Dinophysis spp. in Jinhae Bay, Korea. J. Shellfish Res. 2010, 29, 1061-1067.

36. Hatfield, C.L.; Gauglitz, E.J., Jr.; Barnett, H.J.; Lund, J.A.K.; Wekell, J.C.; Eklund, M. The fate of domoic acid in Dungeness crab (Cancer magister) as a function of processing. J. Shellfish Res. 1995, 14, 359-363. 
37. Choi, M.C.; Yu, P.K.N.; Hsieh, D.P.H.; Lam, P.K.S. Trophic transfer of paralytic shellfish toxins from clams (Ruditapes philippinarum) to gastropods (Nassarius festivus). Chemosphere 2006, 64, 1642-1649.

38. Silva, M.A. Diet of dolphins, Delphinus delphis, off the Portuguese continental coast. J. Mar. Biol. Assoc. UK 1999, 79, 531-540.

39. Blanco, C.; Salomón, O.; Raga, J.A. Diet of the bottlenose dolphin (Tursiops truncatus) in the western Mediterranean Sea. J. Mar. Biol. Assoc. UK 2001, 81, 1053-1058.

40. Reguera, B.; Velo-Suárez, L.; Raine, R.; Park, M.G. Harmful Dinophysis species: A review. Harmful Algae 2012, 14, 87-106.

41. Mangold, K. Eledone Moschata. In Cephalopod Life Cycles: Species Accounts; Boyle, P.R., Ed.; Academic Press: London, UK, 1983; Volume 1, pp. 387-400.

42. Miramand, P.; Bentley, D. Concentration and distribution of heavy metals in tissues of two cephalopods, Eledone cirrhosa and Sepia officinalis, from the French coast of the English Channel. Mar. Biol. 1992, 114, 407-414.

43. Raimundo, J.; Costa, P.; Vale, C.; Costa, M.H.; Moura, I. DNA damage and metal accumulation in four tissues of feral Octopus vulgaris from two coastal areas in Portugal. Ecotoxicol. Environ. Saf. 2010, 73, 1543-1547.

44. Lopes, V.M.; Lopes, A.R.; Costa, P.; Rosa, R. Cephalopods as vectors of harmful algal bloom toxins in marine food webs. Mar. Drugs 2013, 11, 3381-3409.

45. Rosa, R.; Marques, A.M.; Nunes, M.L.; Bandarra, N.; Sousa Reis, C. Spatial-temporal changes in dimethyl acetal (octadecanal) levels of Octopus vulgaris (Mollusca, Cephalopoda): Relation to feeding ecology. Sci. Mar. 2004, 68, 227-236.

46. Kvitek, R.G.; Beitler, M.K. Relative insensitivity of butter clam neurons to saxitoxin: A pre-adaptation for sequestering paralytic shellfish poisoning toxins as a chemical defense. Mar. Ecol. Prog. Ser. 1991, 69, 47-54.

47. Yamassaki, G.E. Dinâmica populacional de Octopus vulgaris (Cuvier, 1797) no Complexo Estuarino de Paranaguá, Paraná, Brasil. B.Sc. Thesis, Universidade Federal do Paraná, Paraná, Brazil, 2011.

48. Balech, E. Los dinoflagelados del Atlántico Sudoccidental. (Publ. Espec. Inst. Esp. Oceanogr.); Ministerio de Agricultura, Pesca y Alimentación: Madrid, Spain, 1988; p. 310.

49. Steidiner, K.A.; Tangen, K. Dinoflagellates. In Identifying Marine Phytoplankton; Tomas, C.R., Ed.; Academic Press: San Diego, CA, USA, 1997; pp. 387-584.

50. Haraguchi, L.; Odebrecht, C. Dinophysiales (Dinophyceae) no extremo Sul do Brasil (inverno de 2005, verão de 2007). Biota Neotrop. 2010, 10, 101-114.

51. Suzuki T.; Jin T.; Shirota T.; Mitsuya T.; Okumura Y.; Kamiyama T. Quantification of lipophilic toxins associated with diarrhetic shellfish poisoning in Japanese bivalves by liquid chromatography-mass spectrometry and comparison with mouse bioassay. Fish. Sci. 2005, 71, 1370-1378.

52. Suzuki, T.; Miyazono, A.; Baba, K.; Sugawara, R.; Kamiyama, T. LC-MS/MS analysis of okadaic acid analogues and other lipophilic toxins in single-cell isolates of several Dinophysis species collected in Hokkaido, Japan. Harmful Algae 2009, 8, 233-238. 
53. Quilliam, M.A.; Hess, P.; Dell'Aversano, C. Recent developments in the analysis of phycotoxins by liquid chromatography-mass spectrometry. In Mycotoxins and Phycotoxins in Perspective at the Turn of the Century, Proceedings of the X International IUPAC Symposium, Guaruja, Brazil, 21-25 May 2000; de Koe, W.J., Samson, R.A., van Egmond, H.P., Gilbert, J., Sabino, M., Eds.; pp. 383-391.

54. Quilliam, M.A. Chemical Method for Lipophilic Shellfish Toxins. In Manual on Harmful Marine Microalgae; Hallegraeff, G.M., Anderson, D.M., Cembella, A.D., Eds.; UNESCO Publishing: Paris, France, 2003; pp. 211-245.

(C) 2015 by the authors; licensee MDPI, Basel, Switzerland. This article is an open access article distributed under the terms and conditions of the Creative Commons Attribution license (http://creativecommons.org/licenses/by/4.0/). 